\title{
Factors Affecting the Yield of Indonesia Government Bonds 10 Years
}

\author{
Intan Permanasari and Augustina Kurniasih
}

\section{ABSTRACT}

The purpose of this research is to analyze the effect of inflation, interest rates, the rupiah exchange rate, and the US 10-Year Treasury on the Indonesian Government Bond Yield. The study population was all yield tenors of the benchmark series Government bonds for the period 2017 to 2019. This study is an associative causality study. The research sample is Indonesian government bonds with a tenor of 10 years. Data were analyzed using multiple linear regression approach. The results show that inflation and US 10-Year Treasury have no effect on the Indonesian Government Bond Yield. Interest rates and the rupiah exchange rate have a positive and significant effect on the Indonesian Government Bond Yield.

Keywords: Inflation, Interest Rates, Rupiah Exchange Rate, US 10Year Treasury, Bond Yield.

\section{INTRODUCTION}

SUN issuance aims to finance the state budget deficit, cover short-term cash shortages and manage the state debt portfolio. It is hoped that the issuance of SUN will be able to explore the potential sources of funding for the State Budget which is bigger than the capital market investors. Law Number 24 of 2002 provides assurance that the Government is required to pay interest and principal on maturing SUN. Every year the Government determines and announces new series of SUN as a new benchmark which serves as a reference for assessing the fairness of securities according to the tenor and coupon rate of each series. Decree of the Director General of Financing and Risk Management Number 64 / PR / 2019 stipulates that the 2020 Benchmark Series SUNs are FR0081 (tenor 5 years), FR0082 (tenor 10 years), FR0080 (tenor 15 years), and FR0083 (tenor 20 years). IDX Annually Statistic 2020 data shows that 10 -year SUN (FR0082) is the most actively traded series in terms of volume. As of November 30, 2020, the trade reached
Submitted : February 15, 2021

Published : February 26, 2021

ISSN: 2507-1076

DOI: $10.24018 /$ ejbmr.2021.6.1.753

\section{Intan Permanasari*}

Mercu Buana University, Jakarta, Indonesia.

(e-mail: permanasariintan ${ }^{@}$ ymail.com)

Augustina Kurniasih

Mercu Buana University, Jakarta,

Indonesia.

(e-mail:

augustina.kurniasih @ mercubuana.ac.id)

*Corresponding Author
IDR78,868 trillion with a frequency of 2,403 times.

Government bonds with a tenor of 10 years are also used as a reference for economic conditions in various countries in the world. Total SBN outstanding as of December 31, 2019 reached Rp. 2,752.74 trillion or an increase of $88.31 \%$ from Rp. 1,461.85 trillion as of December 31, 2015. Bonds are mostly owned by financial institutions, both banks and non-banks. SBN is an alternative for financial institutions when facing poor liquidity. Companies / institutions and individuals buy SBN when there is excess liquidity and sell them to cover liquidity needs. Meanwhile, the increasing foreign ownership of SBN shows that the confidence and interest of foreign investors are also increasing.

In bond investment, the income or return that investors will get from their placement of funds in bonds is called yield. As an investment instrument, changes in bond yields obtained by investors change over time. Bond yields are the main motivation for investors in choosing bond instruments.

TABLE 1: OWNERSHIP OF IDR TRADABLE GOVERNMENT SECURITIES (SBN) FOR THE PERIOD OF 2015-2019

\begin{tabular}{|c|c|c|c|c|c|c|c|c|}
\hline Institution & $\begin{array}{l}31 \text { Des } \\
2015\end{array}$ & $\begin{array}{l}31 \text { Des } \\
2016\end{array}$ & $\begin{array}{c}31 \text { Des } \\
2017\end{array}$ & $\begin{array}{c}31 \text { Des } \\
2018\end{array}$ & $\begin{array}{c}31 \text { Des } \\
2019\end{array}$ & Portion & \multicolumn{2}{|c|}{$\begin{array}{c}\text { Change } \\
2015-2019\end{array}$} \\
\hline BANK & 350.07 & 399.46 & 491.61 & 481.33 & 581.37 & $21.12 \%$ & 231.30 & $66.07 \%$ \\
\hline BANK INDONESIA & 148.91 & 134.25 & 141.83 & 253.47 & 262.49 & $9.54 \%$ & 113.58 & $76.27 \%$ \\
\hline NON BANK & 962.86 & $1,239.57$ & $1,466.33$ & $1,633.65$ & $1,908.88$ & $69.34 \%$ & 946.02 & $98.25 \%$ \\
\hline Mutual Fund & 61.60 & 85.66 & 104.00 & 118.63 & 130.86 & $4.75 \%$ & 69.26 & $112.43 \%$ \\
\hline Insurance & 171.62 & 238.24 & 150.80 & 201.59 & 215.01 & $7.81 \%$ & 43.39 & $25.28 \%$ \\
\hline Non Resident & 558.52 & 665.81 & 836.15 & 893.25 & $1,061.86$ & $38.57 \%$ & 503.34 & $90.12 \%$ \\
\hline Pension Fund & 50.08 & 87.28 & 198.06 & 212.88 & 256.66 & $9.32 \%$ & 206.58 & $412.49 \%$ \\
\hline Individual & 42.53 & 57.75 & 59.84 & 73.07 & 81.18 & $2.95 \%$ & 38.65 & $90.89 \%$ \\
\hline Others & 78.50 & 104.84 & 117.48 & 134.22 & 163.32 & $5.93 \%$ & 84.81 & $108.03 \%$ \\
\hline TOTAL & $1,461.85$ & $1,773.28$ & $2,099.77$ & $2,368.45$ & $2,752.74$ & $100.00 \%$ & $1,290.90$ & $88.31 \%$ \\
\hline
\end{tabular}

Source: DJPPR, Ministry of Finance 2015 - 2019 (data processed). 


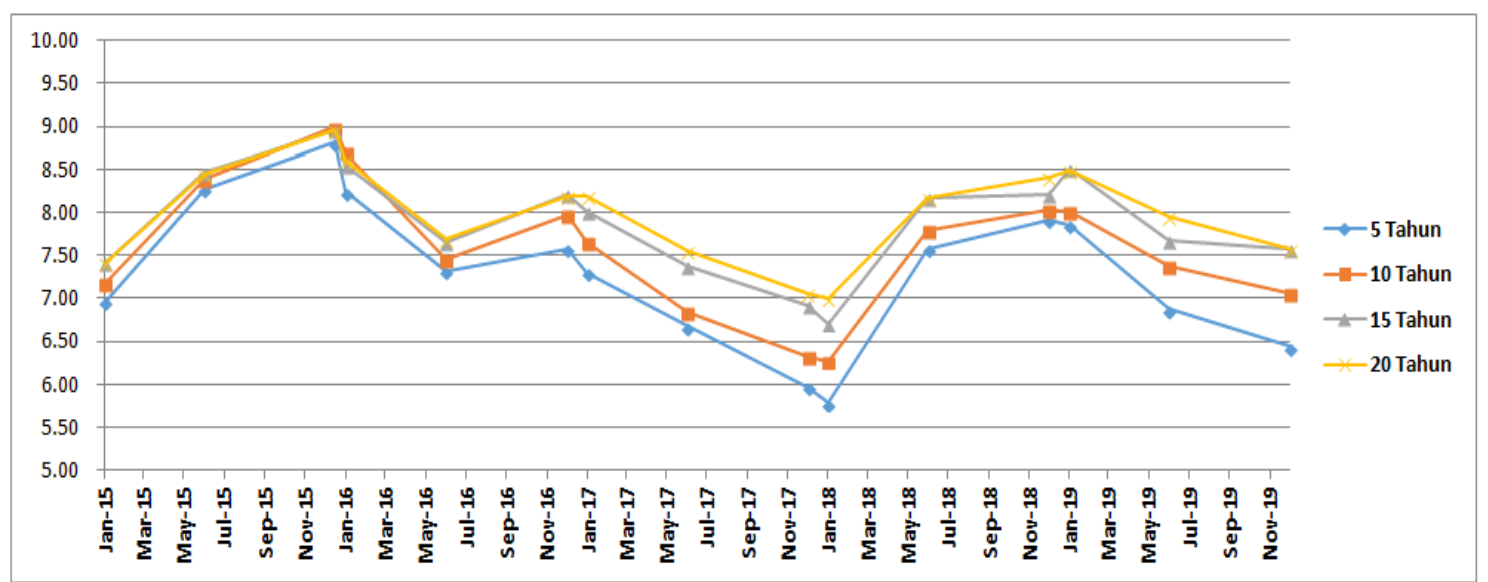

Fig. 1. The Movement of the Indonesian Government Bond Benchmark Series Yield 2015-2019. Source: Bloomberg, 2015 - 2019 (processed data).

Based on Fig. 1, it can be seen that the volatility of the benchmark yield movement of Indonesian Government Bonds in 2015-2019. This volatility is influenced by internal and external factors such as global uncertainty, such as the Fed's interest rate policy, the ongoing trade war between America and China, the conflict between America and Iran, the flow of foreign funds, especially in SBN ownership, to the World Health Organization (WHO) which officially announced the COVID19 outbreak as a global pandemic on March 11, 2020, which had an impact on Indonesia's economic conditions. Therefore, investors need to pay attention to macroeconomic factors that affect these yield changes.

There are several factors that influence changes in bond yields. Tampubolon [1] argues that inflation determines the rise and fall of bond yields. The increase in inflation in the economy will have an impact on the magnitude of risk so that the expected yield will also increase. Kurniasih \& Restika [2], Yusuf \& Prasetyo [3] and Hsing [4] show that inflation has a positive and significant effect on bond yields. In contrast to the research of Yuliawati \& Suarjaya [5], Lumbantobing [6], and Paramita \& Pangestuti [7], it shows that inflation has no effect on bond yields.

Listiawati \& Paramita [8] stated that the increased interest rate causes bond issuers to offer higher yields, so that bond prices in the market will adjust, namely decreasing. Interest rates are an important factor in making investment decisions. High interest rates reflect a large cost of capital so that an increase in interest rates indicates an increase in investment returns. Sihombing \& Sentosa [9], Listiawati \& Paramita [8], and Yieand \& Ng Hui [10] stated that interest rates have a positive effect on bond yields. Meanwhile, the research results of Lumbantobing [6] show that interest rates do not have a significant effect on bond yields. Nurfauziah \& Setyarini [11] and Wulandari [12] show that interest rates have a negative and insignificant effect on bond yields. According to Gadanecz et al [13], the exchange rate is one of the factors that greatly influences the domestic bond yield of a country.

Foreign investors are exposed to the risk of lowering the value of their investment in debt securities due to depreciation of the local currency. Yield will increase in line with the weakening of the exchange rate. Thus, the expectation of an increase or decrease in the value of a country's currency will affect the yield requested. According to Tandelilin [14], the strengthening of the rupiah exchange rate against the US dollar is a positive signal for the economy. On the other hand, the weakening of the rupiah exchange rate will give a negative signal to the economy, which makes investing in Indonesia riskier. Surya \& Nasher [15], Jaramillo \& Weber [16], Muktiyanto \& Aulia [17], and Sihombing \& Adiwibowo [18], show that exchange rates have a positive and significant effect on bond yields. In contrast to the research of Lumbantobing [6] which shows that the exchange rate has no effect on yield and Hsing [4] which shows that the exchange rate has a negative and significant effect on bond yields.

Miyajima et al [19] stated that the US Treasury rate of return is one of the dominant factors shaping the yield of domestic debt securities in various developing countries, especially during the period of monetary policy easing by the Central Bank of developed countries as a response to the global economic crisis in 2008-2009 ago.

The disbursement of stimulus by means of purchasing debt securities or other financial assets issued by the Government in developed countries at that time pushed down the yields of sovereign bonds, including the US Treasury, which made investment in developing countries more attractive because of their relatively high yields. Muktiyanto \& Aulia [17] and Yusuf \& Prasetyo [3] state that the US Treasury has a positive and significant effect on yield, while Priyatna's [20] research results show that the US Treasury has no effect on bond yields. This study aims to find empirical evidence of the effect of inflation, interest rates, the rupiah exchange rate and the US 10-Year Treasury on the 10-year tenor Indonesian government bond yield. The 10 -year tenor bond is the most actively traded bond and is a reference for the economic conditions of various countries in the world.

\section{LITERATURE REVIEW}

Signal theory was first introduced by Spence in 1973 in his research entitled Job Market Signaling. This theory deals with information asymmetry in which investors do not have the same information as a country or company regarding the prospects or risks of a country or company. According to Brigham and Hauston [21] a signal is an action taken by a 
company to provide guidance to investors about how management views the company's prospects. This signal can be in the form of data related to economic conditions submitted by the Government that may cause changes in bond yields such as inflation, interest rates and the Rupiah exchange rate. The information released by the Government is important because it can influence investment decisions by investors.

Interest Rate Parity Theory analyzes the relationship between changes in currency rates and changes in interest rates. Interest rate parity is an equilibrium condition in which the difference in interest rates between two currencies is offset by the difference between the forward rate and the spot rate [22]. From this theory, it is concluded that the exchange rate is influenced by the difference or difference between domestic interest rates and foreign interest rates. The Purchasing Power Parity theory states that the exchange rate will adjust over time to reflect the difference in inflation between two countries so that the purchasing power of consumers to buy foreign products will be the same if it is measured in the same currency [23]. This means that the exchange rate of a country's currency will change as a reaction to the difference in inflation between the two countries and the purchasing power of consumers when buying products will be the same as the purchasing power when importing from other countries.

According to Madura [23], the International Fisher Effect (IFE) uses the interest rate as inflation, to explain exchange rates change over time, but this theory is closely related to the PPP theory because interest rates are often closely related to the inflation rate. Investors from all countries want the same return, the difference in interest rates between countries may be the result of differences in inflation estimates. The interest rate is one of the economic variables that is often monitored by economic actors. Interest rates are seen as having a direct impact on economic conditions. When interest rates increase, the expected returns will also increase.

Zulfikar [24] said bond yields are the returns that investors expect when investing in bonds. Yield is not fixed, like bond coupons, because bond yields will be closely related to the return level indicated by investors [14].

Inflation is a phenomenon in which prices increase continuously [14]. Nurfauziah \& Setyarini [11] concluded that fluctuating inflation has an impact on investment in securities because increasing inflation means investing in securities such as bonds is considered riskier, the high risk in investment will result in higher yields expected by investors. Mishkin [25] suggests that interest rates are costs contained in a loan, so that an increased interest rate has an impact on the amount of yield expected by investors on bond instruments.

Tandelilin [14] also states that high interest rates will cause returns which indicate investors from an investment will increase. The exchange rate is a unit of currency that is bought or sold against other currencies [26]. The high exchange rate of a country's currency will have an impact on economic conditions so that the yield of bonds issued in that country is expected to be higher [27]. Lower yields in developed countries, such as the United States, have encouraged investors to invest in assets in developing countries that have relatively high yields. This in turn has contributed to the decline in yield on bonds in developing countries [19].

Based on the literature above, a research framework is prepared that shows the relationship between variables.

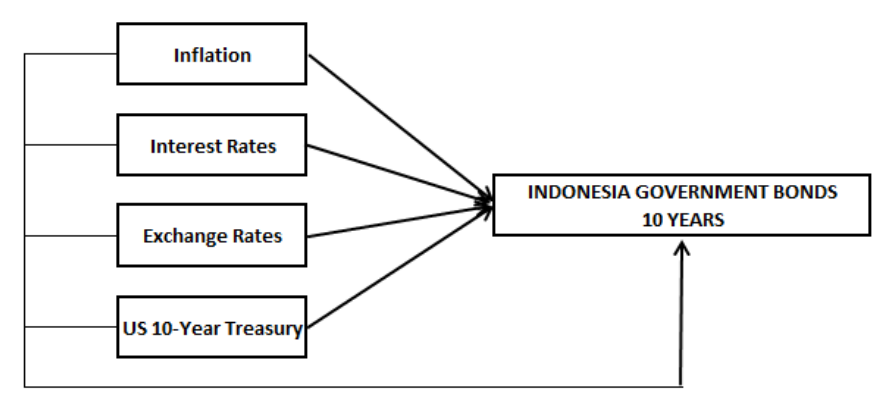

Fig. 2. Framework.

\section{METHOD}

This research is a causality research that is testing the causal relationship between one variable and another through hypothesis testing. The study population was all Indonesian Government bonds with a benchmark tenor (5 years, 10 years, 15 years and 20 years) in the period January 2017 to December 2019, totalling 144 bonds. The research sample consisted of 10-year tenor Indonesian government bond yields.

The data analysis technique used to analyze the effect of independent variables on the dependent variable is multiple linear regression models. The regression equation proposed is:

$$
Y t=a+b 1 X 1 t+b 2 X 2 t+b 3 X 3 t+b 4 X 4 t+e
$$

where

$\mathrm{Y}$ : Indonesian government bond yields with a tenor of 10 years,

a : Contant,

b : b1, b2, b3, b4 Coefficient Regression,

$\mathrm{X} 1$ : Inflation,

X2 : BI 7-Day (Reverse) Repo Rate,

X3 : The Exchange Rate of Rupiah against US Dollars,

X4 : US 10-Year Treasury,

e : standard error.

\section{RESUlt AND Discussion}

Table 2 presents descriptive statistics of the research variables. The lowest value of inflation was $2.48 \%$ which occurred in March 2019, which was triggered by slowing inflation in the core group and volatile food group which recorded deflation. The highest inflation occurred in June 2017 at $4.37 \%$ driven by adjustments to electricity rates, as well as increases in air and intercity transportation rates. Meanwhile, food prices, which are usually the main contributor during the month of Ramadan, are relatively under control. 


\begin{tabular}{ccccc}
\multicolumn{5}{c}{ TABEL 2: Descriptive StATISTICS } \\
\hline & Minimum & Maximum & Mean & $\begin{array}{c}\text { Std. } \\
\text { Deviation }\end{array}$ \\
& & & & 0.439 \\
Inflation & 2.48 & 4.37 & 3.35 & 0.439 \\
Interest Rate & 4.25 & 6.00 & 5.10 & 0.661 \\
Rupiah exchange rate & $13,319.00$ & $15,227.00$ & $13,932.03$ & 499.820 \\
US 10-Year Treasury & 1.50 & 3.14 & 2.43 & 0.421 \\
10 Year Bond Yield & 6.27 & 8.54 & 7.29 & 0.582 \\
\hline
\end{tabular}

The interest rate variable has the lowest value of $4.25 \%$ which occurred in September 2017 to April 2018. The results of the Bank Indonesia (BI) Board of Governors Meeting (RDG) on September 20-22 2017, it was decided that the benchmark interest rate was reduced by $25 \mathrm{bps}$ from the amount of $4.50 \%$ to $4.25 \%$. It is hoped that the reduction in interest rates will support the improvement of bank intermediation in channelling credit and the sustainable recovery of the domestic economy. The highest interest rate of $6.00 \%$ occurred during the fourth quarter of 2018 to the second quarter of 2019. Based on RDG Graphic Info in November 2018, this is BI's next step to strengthen efforts to reduce the current account deficit to a safe limit and to strengthen the attractiveness of domestic financial assets by anticipating increases in global interest rates.

The rupiah exchange rate against the US dollar had the lowest value of 13,319.00 in June 2017. Based on the 2017 Indonesian Economic Report from Bank Indonesia, the rupiah exchange rate moved stable in 2017 with low volatility. This is supported by several fundamental factors, such as the Indonesian Balance of Payments (BOP) which recorded a surplus, improved micro-conditions on the foreign exchange market, and Bank Indonesia policies that consistently directed the exchange rate according to its fundamental value amid external risks that occurred in 2017. Exchange rates the highest rupiah against the US dollar occurred in October 2018, amounting to 15,227.00 which was caused by a trade war between the United States (US) and China which resulted in emerging market countries experiencing exchange rate depreciation including Indonesia.

The lowest value of the US 10-Year Treasury variable of $1.50 \%$ occurred in February 2019. This was caused by an inversion in the bond yields of the United States (US) due to concerns from global market players predicting the magnitude of the potential for a US economic recession as a result of trade relations between the US and China which heating up. The highest US 10-Year Treasury occurred in October 2018 at $3.14 \%$ which was triggered by US employment data which showed positive results, triggering positive sentiment towards the investment climate in the US.

The 10-year tenor (Y) Indonesian Government Bond Yield in this study based on the results of descriptive statistics had the lowest value of $6.27 \%$ in January 2018.The highest value for the 10-year tenor Indonesian government bond yield occurred in October 2018 at $8.54 \%$ which was driven by Market concerns about rising global bond yields, following market expectations of a plan to increase the fed funds rate (FFR) of up to 4 times during 2018.

\section{TEST Result}

Table 3 presents the test results of the regression model regarding the effect of inflation, interest rates, exchange rates, and US 10-Year Treasury on the Indonesian Government Bond Yield Tenor 10.

\begin{tabular}{ccccc}
\multicolumn{6}{c}{ TABLE 3: RESULTS OF MULTIPLE LINEAR REGRESSION ANALYSIS } \\
\hline & $\mathrm{B}$ & Std. Error & $\mathrm{t}$ & Sig. \\
\hline (Constant) & -0.026 & .035 & -.740 & 0.465 \\
Inflation & 0.132 & .153 & .858 & 0.398 \\
Interest Rate & 0.422 & .199 & 2.117 & 0.043 \\
Rupiah exchange rate & 0.001 & .000 & 5.353 & 0.000 \\
US 10-Year Treasury & 0.279 & .213 & 1.311 & 0.200 \\
{$[1]$} & R $^{2}$ & $\mathbf{0 , 5 6 9}$ \\
{$[2]$} & Adj-R & $\mathbf{0 , 5 1 1}$ \\
{$[3]$} & F-statistic & $\mathbf{9 , 8 9 3}$ \\
{$[4]$} & Prob(F-statistic) & $\mathbf{0 , 0 0 0}$ \\
\hline
\end{tabular}

The regression model is built accordingly, it is concluded from the Fcount value of 9,893 with a significance of 0,000 . $\mathrm{R}$ square or the coefficient of determination is 0.569 , indicating that the regression model is able to explain $56.9 \%$ of the variability of the 10-year tenor Indonesian government bond yield. There is still $43.1 \%$ influence from other factors, apart from inflation, interest rates, exchange rates, and the US 10-Year Treasury that affect the 10-year tenor Indonesian government bond yield.

Hypothesis test results show that inflation and US 10Year Treasury partially do not affect the 10-year tenor Indonesian Government Bond Yield. This is because the significance value is $>0.05$. Interest Rates and the Rupiah Exchange Rate against the US Dollar have a positive and significant effect on the 10-year tenor Indonesian Government Bond Yield, due to the significance value $<0.05$.

The results show that inflation does not have a significant effect on bond yields, in line with the results of Listiawati \& Paramita's [8] research on corporate bond yields listed on the Indonesia Stock Exchange in the period 2010-2016) who found that there was no effect of inflation on Indonesian Government bond yields. The inflation rate that occurred during the study period (January 2017 - December 2019) was classified as stable and was always below $10 \%$ each year. Inflation of less than $10 \%$ can still be accepted by the market because the inflation rate is still in the low category, so it has not been able to affect the yield of Indonesian Government bonds.

Interest rates were found to have a positive and significant effect on bond yields. The interest rate is one of the economic variables that is often monitored by economic actors. Interest rates have a direct impact on the economy. Various decisions related to consumption, saving and investment are closely related to interest rate conditions. Interest rates are a reference for buyers of debt securities such as bonds as a basic comparison of the rate of expected return. When market interest rates change, it will affect the price of debt securities. When the market interest rate increases, it will affect the return on debt securities which will increase. These findings support the theory of the interest rate, where when interest rates increase, the bond issuer will provide higher yields [14]. The results of this study are in line with Yuliawati \& Suarjaya [5], Jaramillo \& Weber [16] and Kurniasih \& Restika [2] who found that 
interest rates have a positive and significant effect on bond yields.

The rupiah exchange rate against the US dollar was found to have a positive and significant effect. This indicates that the relationship between the rupiah exchange rate and bond yield is unidirectional, meaning that the stronger the rupiah exchange rate against the US dollar, the lower the bond yield. The strengthening of the rupiah exchange rate and the decline in bond yields illustrates that investment risks in Indonesia are reduced and economic conditions are in good condition. The results obtained are consistent with the theory, where the strengthening of the Rupiah exchange rate against the US Dollar is a positive signal for the economy [14]. The results of this study support the findings of Surya \& Nasher [15], Sihombing \& Adiwibowo [18], and Hsing [4].

The US 10-Year Treasury was found to have no significant effect on bond yields. The results of this study are not in line with Yusuf \& Prasetyo [3] who show that the US 10-Year Treasury has a significant effect on the yield of Indonesian Government bonds with a tenor of 10 years. This is driven by the investment grade rating of Indonesian government bonds that attracts global investors so that fluctuations in the US bond market will have an impact on the bond market in Indonesia. This finding does not support Miyajima et al. [19] which states that the US Treasury is the dominant factor shaping the yield of developing countries' debt securities. The stimulus carried out by the Central Banks of developed countries during the global economic crisis of 2008-2009 through the issuance of debt securities led to a decline in bond yields in developed countries which led investors to invest in developing countries which gave relatively high yields.

However, Miyajima et al. [19] are also aware of the shocks that may arise on financial markets in developing countries when the cycle ends. Changes in the US Treasury during the study period (January 2017 - December 2019) which are classified as stable have not been able to affect the Indonesian Government bond yields. This may be due to internal macroeconomic factors that have more influence on government bond yields as well as the relatively stable share of foreign investor ownership during the study period as well as the larger portion of domestic ownership in SBN compared to foreign ownership. This finding also does not support the research conducted by Miyajima, et al [19] and Hsing [4]. The results of this study are in line with Priyatna's [20] research which shows that the US 10-Year Treasury has no influence on the yields of Indonesian international bonds denominated in USD in the period December 2007 to June 2016. The effect of interest rates was found to be greater than the effect of exchange rates. This means that investors and policy makers need to pay more attention to interest rates related to bond investment.

\section{CONCLUSION AND SUGGESTION}

The results showed that partially inflation and US 10Year Treasury have no effect on bond yields. Meanwhile, interest rates and rupiah exchange rates have a positive and significant effect on bond yields.
It is recommended that investors consider the interest rate and the rupiah exchange rate in obtaining a return on bond investment considering that these two variables have a significant effect. The government, as the bond issuer as well as the policy maker, needs to pay attention to the impact of the monetary policies taken, particularly policies that can affect interest rates and the rupiah exchange rate. As a refinement, further research should add to other macroeconomic factors such as Gross Domestic Product (GDP) or Sovereign Risk such as Credit Default Swaps (CDS) and other external factors such as the Fed's interest rate as a determining factor in bond yields. This research model can be implemented in other types of bonds. This research model can be applied to future research with a longer research period.

\section{REFERENCES}

[1] Tampubolon, G. (2007), "Analisis Faktor Determinan yang Mempengaruhi Yield Obligasi: Pendekatan VAR", Tesis, Magister Manajemen, Univesitas Indonesia, Jakarta.

[2] Kurniasih, A \& Restika, Y. (2015). The influence of Macroeconomic Indicators and Foreign Ownership on Government Bond Yields: A Case of Indonesia. Mediterranean Journal of Social Sciences, 6 (5), 34-42.

[3] Yusuf, Achlanuddin \& Prasetyo, Ahmad Danu, 2019, "The Effect of Inflation, US Bond Yield, and Exchange Rate on Indonesia Bond Yield", Jurnal Perspektif Pembiayaan dan Pembangunan Daerah, Vol 6. No 6, 649 - 656.

[4] Hsing, Yu 2015, "Determinants of the Government Bond Yield in Spain: A Loanable Funds Model. International Journal of Financial Studies", 3 (3). pp. 342-350.

[5] Yuliawati, Devi \& Suarjaya, A.A Gede, (2017). Pengaruh Umur Obligasi, Tingkat Suku Bunga, dan Inflasi pada Imbal Hasil Obligasi Pemerintah di BEI. E-Jurnal Manajemen Unud, Vol. 6, No. 11, 2017: 6187-6215.

[6] Lumbantobing, Andri Lambas 2014, "Pengaruh Inflasi, Nilai Tukar Rupiah, Suku Bunga Pasar Uang Domestik dan Suku Bunga Pasar Uang Luar Negeri terhadap Yield to Maturity Obligasi Ritel. Jurnal MIX, Vol IV, No 2, 151-173.

[7] Paramita, Rio Putri \& Pangestuti, Irene Rini Demi 2016, " Determinan Yield Obligasi Pemerintah Tenor 5 Tahun dengan Menggunakan Model EGARCH pada Negara Indonesia, Malaysia, Thailand, dan Filipina", Diponegoro Jurnal of Management, Vol. 5, Nomor 3, 1-14.

[8] Listiawati, L. N., \& Paramita, V. S. (2018). Pengaruh Tingkat Suku Bunga , Inflasi , Debt To Equity Ratio , Dan Ukuran Perusahaan Terhadap Yield Obligasi Pada. Jurnal Manajemen, 15(1), 33-51.

[9] Sihombing, Pardomuan \& Perdana Wahyu Sentosa. (2015). Factors Affecting the yield curve Fluctuation of Indonesia Government Bond (Indonesian Government Bond Yield Curve). I J A B E R, Vol. 13, No. 6 (2015): 4073-4087.

[10] Yieand, Chong Veng \& Ng Hui Chen. (2019). Determinant of Bond Yield (Periode 2006-2016 on Malayasian Government Bond Yield). International Journal of Recent Technology and Engineering (IJRTE), ISSN: 2277-3878, Volume-7 Issue-5S.

[11] Nurfauziah, \& Setyarini, A. F. 2004, “Analisis Faktor-faktor yang Mempengaruhi Yield Obligasi Perusahaan (Studi Kasus Pada Industri Perbankan dan Industri Finansial)", Jurnal Siasat Bisnis, 9(2): 241 256.

[12] Wulandari, Dian. (2017), "Pengaruh Tingkat Asuku Bunga, Peringat Obligasi dan Debt to Equity Ratio (DER) terhadap Yield Obligasi Korporasi", Tesis, Magister Manajemen, Universitas Mercu buana, Jakarta.

[13] Gadanecz, Blaise, Ken Miyajima \& Chang Shu 2014, "Exchange Rate Risk and Local Currency Sovereign Bond Yields in Emerging Market", BIS Working Paper No. 474.

[14] Tandelilin, Eduardus, 2010. Portofolio dan Investasi Teori dan Aplikasi. Jakarta: Kanisius.

[15] Surya, B., \& Nasher, T. 2011, "Analisis Pengaruh Tingkat Suku Bunga SBI, Exchange Rate, Ukuran Perusahaan, Debt to Equity Ratio Dan Bond Terhadap Yield Obligasi Korporasi Di Indonesia," Tesis, Magister Administrasi Bisnis, Institut Teknologi Bandung, Bandung. 
[16] Jaramillo \& Weber. 2013,' Global Spillovers into Domestic Bond Markets in Emerging Market Economics.' IMF Working Paper, JEL Classification Numbers: E44, E62, G15, H63, O16.

[17] Muktiyanto, Ihda \& Aulia, Muhammad 2019, "Determinan Tingkat Imbal Hasil (Yield) Surat Berharga Negara (SBN) Domestik", Kajian Ekonomi dan Keuangan, Vol.3, Nomor.2, 18-30.

[18] Sihombing, Pardomuan \& Priyo Adiwibowo. (2019). Determinant of Govermement Bond Yields. E-ISSN: 2715-4203: 2715-419X, Volume 1, Issue 1.

[19] Miyajima, K., Mohanty, M. S., \& Chan, T. (2012). Emerging market local currency bonds: Diversification and stability. Emerging Markets Review, 22 (391), 126-139.

[20] Priyatna, Galing 2016, "Analisis Pengaruh Faktor Global Terhadap Yield Spread Obligasi Internasional Indonesia Berdenominasi USD", Tesis, Magister Manajemen, Universitas Gadjah Mada, Yogyakarta.

[21] Hauston, Joel F. dan Brigham, Eugene F. 2011. Dasar-dasar Manajemen Keuangan Terjemahan. Edisi 10. Jakarta: Salemba Empat.Ekananda, Mahyus. 2014, Ekonomi Internasional, Jakarta: Erlangga.

[22] Madura, 2006, "Pengaruh Jumlah Uang Beredar (Jub), Suku Bunga Sertifikat Bank Indonesia (Sbi), Impor, Ekspor Terhadap Kurs Rupiah/ Dollar Amerika Serikat Periode Januari 2006 sampai Maret 2010", Skripsi, Fakultas Ekonomi dan Bisnis, Universitas Negeri Semarang, Semarang.

[23] Zulfikar. (2016). Pengantar Pasar Modal Dengan Pendekatan Statistika. Jakarta :CV Budi Utama.

[24] Mishkin, F. (2010). Ekonomi Uang, Perbankan, dan Pasar Keuangan. Salemba Empat.

[25] Wiagustini, N. L. P. (2014). Dasar-Dasar Manajemen Keuangan. Bali : Udayana University Press.

[26] Triyono, T. (2008). Analisis Perubahan Kurs Rupiah Terhadap Dollar Amerika. Jurnal Ekonomi Pembangunan: Kajian Masalah Ekonomi Dan Pembangunan, Vol. 9, No. $2: 156$.

[27] Sihombing, Pardomuan. (2014). Determinan Yield Curve Surat Utang Negara (SUN). Disertasi. Institut Pertanian Bogor, Bogor.

[28] Brigham, Eugene F. dan Hauston, Joel F. 2011. Dasar-dasar Manajemen Keuangan Terjemahan. Edisi 10. Jakarta: Salemba Empat.

[29] Muharam, Harjum, 2013, "Government Bond Yield Volatility and Its Determinants: The Case Of Indonesia Government Bond", Disertasi, Fakultas Ekonomi dan Bisnis, Universitas Diponegoro, Semarang.

[30] Spence, Michael 1973, "Job Market Signalling The Quarterly Journal of Economics," The MIT Press, Agustus, Vol. 87 No. 3, 39.

[31] Wiyani, 2005, Pengaruh Nilai Tukar Rupiah, Suku Bunga SBI, Volume Perdagangan Saham, Inflasi, dan Beta Saham terhadap Harga Saham. Jurnal Manajemen Universitas Diponegoro, 45, 70-72. 